\title{
Three junior synonyms of jumping spider genera (Araneae: Salticidae)
}

\section{Три новых синонима среди родов пауков-скакунчиков (Araneae: Salticidae)}

\section{Theo Blick ${ }^{1,2}$, Yuri M. Marusik ${ }^{3,4}$ \\ Т. БАик, Ю.М. Марусик}

\footnotetext{
${ }^{1}$ Hummeltal, Germany. E-mail: info@theoblick.de

${ }^{2}$ World Spider Catalog, Natural History Museum Bern, Switzerland

${ }^{3}$ Institute for Biological Problems of the North, Magadan, 685000 Russia. E-mail: yurmar@mail.ru

${ }^{4}$ Zoology \& Entomology, University of the Free State, Bloemfontein, South Africa.

${ }^{3}$ Институт биологических проблем Севера ДВО РАН, ул. Портовая 18, Магадан 685000 Россия.
}

KEY WORDS: Calositticus, Colopsus, Evacin, Hypositticus, Sitticus, Sittiflor, Sittipub.

КЛЮЧЕВЫЕ СЛОВА: Calositticus, Colopsus, Evacin, Hypositticus, Sitticus, Sittiflor, Sittipub.

ABSTRACT. Three generic names recently described by J. Prószyński were found to be junior synonyms, either objective (Sittipub Prószyński, $2016=$ Hypositticus Lohmander, 1944) or subjective (Sittiflor Prószyński, $2017=$ Calositticus Lohmander, 1944 and Evacin Prószyński, 2018 = Colopsus Simon, 1902). Two earlier subgenera of Sitticus Simon, 1901, Calositticus Lohmander, 1944 and Hypositticus Lohmander, 1944, are elevated to genus rank.

How to cite this article: Blick Th., Marusik Yu.M. 2018. Three junior synonyms of jumping spider genera (Araneae: Salticidae) // Arthropoda Selecta. Vol.27. No.3. P.237-238. doi: 10.15298/arthsel. 27.3.07

РЕЗЮМЕ. Синонимизированы три родовых названия недавно предложенных J. Prószyński. Одно название является объективным синонимом (Sittipub Prószyński, 2016 = Hypositticus Lohmander, 1944), a два названия - субъективные синонимы (Sittiflor Prószyński, 2017 = Calositticus Lohmander, 1944 и Evacin Prószyński, 2018 = Colopsus Simon, 1902). Ранг двух таксонов, считавшихся подродами Sitticus Simon, 1901, повышен до родового уровня: Calositticus Lohmander, 1944 и Hypositticus Lohmander, 1944.

\section{Introduction}

In the last decade the spider family Salticidae was subject to several revisions dealing with classification at the subfamily and tribe levels [e.g., Maddison, 2015; Maddison et al., 2017], and Prószyński [2016, 2017, 2018] proposed an extensive splitting of several species-rich genera (e.g., Evarcha Simon, 1902, Myrmarachne MacLeay, 1839, Sitticus Simon, 1901, Yllenus Simon, 1868). The descriptions of the new genera were not of a good standard [cf. Kropf et al., 2018]. While studying these newly erected genera, we found at least three of them to be either subjective or objective junior synonyms:

\section{Survey of taxa}

Calositticus Lohmander, 1944, stat.n.

Calositticus Lohmander, 1944: 5 (type Attus caricis Westring, 1861; as a subgenus of Sitticus Simon, 1901).

Sittiflor Prószyński, 2017: 43 (type Euophrys floricola C.L. Koch, 1837), syn.n.

COMMENT. Calositticus was described as a monotypic subgenus of Sitticus. Sittiflor was described to accommodate the species of the Sitticus floricola group containing 13 species [WSC, 2018]. Sitticus caricis belongs to this group and was included by Prószyński [2017] in Sittiflor. Therefore, Sittiflor is a subjective junior synonym of Calositticus.

Colopsus Simon, 1902

Colopsus Simon, 1902: 409 (type Colopsus cancellatus Simon, 1902).

Evacin Prószyński, 2018: 141 (type Evarcha kochi Simon, 1902), syn.n.

COMMENT. Colopsus was described as a monotypic genus and was synonymized with Evarcha by Prószyński [1984: 51]. Prószyński [2018] placed Evarcha cancellata in his new genus Evacin encompassing 21 species [Prószyński, 2018], hence Evacin is a subjective junior synonym of Colopsus.

Hypositticus Lohmander, 1944 stat.n.

Hypositticus Lohmander, 1944: 5 (type Aranea pubescens Fabricius, 1775; as a subgenus of Sitticus Simon, 1901).

Sittipub Prószyński, 2016: 27 (type Aranea pubescens Fabricius, 1775), syn.n.

COMMENT. Hypositticus was described as a monotypic subgenus of Sitticus. Sittipub was described to 
accommodate two species, Sitticus pubescens and $S$. relictarius Logunov, 1998. Both genera have the same type species, therefore they are objective synonyms.

\section{Acknowledgements}

Our thanks go to Rainer Breitling for confirming the synonymies with Lohmander's subgenera, to Jason Dunlop for a linguistic check of an earlier version of the text and finally to the anonymous reviewers.

\section{References}

Kropf C., Blick T., Brescovit A.D., Chatzaki M., Duperré N., Gloor D., Haddad C.R., Harvey M.S., Jäger P., Marusik Yu.M., Ono H., Rheims C.A., Nentwig W. 2018 (submitted). How not to delimit taxa: a critique on a recently proposed "pragmatic classification" of jumping spiders (Arthropoda: Arachnida: Araneae: Salticidae) // Zootaxa.

Lohmander H. 1944. Vorläufige Spinnennotizen // Arkiv för Zoologi. Vol.35. Ser.A. Nr.16. S.1-21.

Maddison W.P. 2015. A phylogenetic classification of jumping spiders (Araneae: Salticidae) // Journal of Arachnology. Vol.43. No.2. P.231-292.
Maddison W.P., Evans S.C., Hamilton C.A., Bond J.E., Lemmon A.R., Lemmon E.M. 2017. A genome-wide phylogeny of jumping spiders (Araneae, Salticidae), using anchored hybrid enrichment // ZooKeys. Vol.695. P.89-101.

Prószyński J. 1984. Atlas rysunków diagnostycznych mniej znanych Salticidae (Araneae), 2. Siedlce: Wyższa Szkoła Rolniczo-Pedagogiczna. 177 pp.

Prószyński J. 2016. Delimitation and description of 19 new genera, a subgenus and a species of Salticidae (Araneae) of the world // Ecologica Montenegrina. Vol.7. P.4-32.

Prószyński J. 2017. Revision of the genus Sitticus Simon, 1901 s. l. (Araneae: Salticidae) // Ecologica Montenegrina. Vol.10. P.3550.

Prószyński J. 2018. Review of genera Evarcha and Nigorella, with comments on Emertonius, Padilothorax [sic], Stagetillus, and description of five new genera and two new species (Araneae: Salticidae) // Ecologica Montenegrina. Vol.16. P.130-179.

Simon E. 1902. Descriptions d'espèces nouvelles de la famille des Salticidae (suite) // Annales de la Société Entomologique de France. T.71. P.389-421.

WSC 2018. World Spider Catalog. Version 19.5. Available from: http://wsc.nmbe.ch (accessed 8.08.2018)

Responsible editor S. Koponen 